\title{
Effects of sodium butyrate on expression of members of the IGF-binding protein superfamily in human mammary epithelial cells
}

\author{
J Tsubaki, W-K Choi, A R Ingermann, S M Twigg, H-S Kim, \\ R G Rosenfeld and Y Oh
}

Department of Pediatrics, Oregon Health Sciences University, Portland, Oregon 97201, USA

(Requests for offprints should be addressed to Y Oh, Department of Pediatrics, School of Medicine, NRC 5, Oregon Health Sciences University, 3181 Southwest Sam Jackson Park Road, Portland, Oregon 97201-3042, USA; Email: ohy@ohsu.edu)

\begin{abstract}
Dietary factors play an important role in both the development and prevention of human cancers, including breast carcinoma. One dietary micronutrient, sodium butyrate $(\mathrm{NaB})$, is a major end product of dietary starch and fiber, produced naturally during digestion by anaerobic bacteria in the cecum and colon. $\mathrm{NaB}$ is a potent growth inhibitor and initiates cell differentiation for many cell types in vitro. In this study, we investigated the effects of $\mathrm{NaB}$ on three human mammary epithelial cells and regulation of the IGF axis, specifically, IGF-binding protein-3 (IGFBP-3), a known growth regulator in human mammary cells, and IGFBP-related protein 2 (IGFBP-rP2)/connective tissue growth factor.

$\mathrm{NaB}$ inhibited DNA synthesis, as measured by $\left[{ }^{3} \mathrm{H}\right]$ thymidine incorporation, in estrogen-responsive (MCF-7) and estrogen-non-responsive (Hs578T) breast cancer cells, and normal human mammary epithelial cells (HMEC) to a similar degree (up to $90 \%$ inhibition at 1-10 mM concentrations). Treatment of cells with $\mathrm{NaB}$ induced histone hyperacetylation, suggesting that $\mathrm{NaB}$ exerts its biological effects, at least in part, as a histone deacetylase inhibitor in mammary epithelial cells. Treatment of Hs578T cells with $\mathrm{NaB}$ caused an induction of apoptotic cell death. $\mathrm{NaB}$ treatment resulted in increased levels of
\end{abstract}

$\mathrm{p} 21^{\text {Waf1/Cip1 }} \mathrm{mRNA}$ and protein in Hs578T cells and distinct upregulation of $\mathrm{p} 27^{\mathrm{Kip} 1}$ in HMEC, suggesting that $\mathrm{NaB}$ activates different genes involved in cell cycle arrest, depending upon the cell type. In the same context, among the IGFBP superfamily members tested, $\mathrm{NaB}$ specifically upregulated the expression of IGFBP-3 and IGFBP-rP2. These two proteins are known to be involved in inhibition of mammary epithelial cell replication. Northern blot analysis showed that $\mathrm{NaB}$ treatment at $1-10 \mathrm{mM}$ concentrations caused a dose-dependent stimulation of IGFBP-3 mRNA expression in cancerous cells and IGFBP-rP2 mRNA expression in both cancerous and non-cancerous cells. Protein data from Western ligand blot and immunoblot analyses demonstrated parallel results.

In summary, we have demonstrated that $\mathrm{NaB}$ (i) uniformly suppresses DNA synthesis in both cancerous and non-cancerous mammary cells, and (ii) upregulates IGFBP-3 and IGFBP-rP2 mRNA and protein levels in cancerous and non-cancerous mammary cells. These results provide the first demonstration that butyrate regulates the IGFBP system in the human mammary system.

Journal of Endocrinology (2001) 169, 97-110

\section{Introduction}

Butyric acid is a 4-carbon fatty acid which is the major product from microbial fermentation of dietary fibers in the large intestine (Velázquez et al. 1997). It is a potent growth inhibitor and initiates cell differentiation in several cell types, including breast cancer cells in vitro (Coradini et al. 1997, Velázquez et al. 1997, Gleave et al. 1998, Yamamoto et al. 1998). Although the molecular mechanisms by which butyrate exerts its effects are still unclear, it is known to induce a number of alterations within the nucleus, including histone hyperacetylation (de Haan et al. 1986, Archer \& Hodin 1999).
It has been reported that butyrate, as well as trichostatin A (TSA), a specific histone deacetylase inhibitor (Yoshida et al. 1990), modulates specific genes involved in cell cycle regulation and apoptosis. These include the cyclindependent kinase (cdk) inhibitor $\mathrm{p} 21^{\text {Waf1/Cip } 1}$ (Archer et al. 1998), $\mathrm{p} 16^{\mathrm{INK} 4}$ (Schwartz et al. 1998), $\mathrm{p} 27^{\mathrm{Kip} 1}$ (Litvak et al. 1998), retinoblastoma protein (Vaziri et al. 1998), cyclin D1 (Lallemand et al. 1996, Siavoshian et al. 1997), Bcl-2 and Bax (Mandal \& Kumar 1996, Hague et al. 1997). Furthermore, butyrate has also been reported to upregulate the expression of transforming growth factor- $\beta$ (TGF- $\beta$ ) (Staiano-Coico et al. 1990), which is known to be involved in growth suppression of various 
cancer cells, including breast cancer cells (Knabbe et al. 1987).

Insulin-like growth factors (IGFs) are potent mitogens for several cell types (Macaulay 1992, Resnicoff et al. 1995). The IGF system consists of IGF-I and IGF-II ligands, the transmembrane type I and type II IGF receptors, the IGF-binding proteins (IGFBPs) and IGFBP proteases (Hwa et al. 1999). Recently, the concept of the IGFBP superfamily has been proposed (Baxter et al. 1998); it consists of high affinity IGF binders (IGFBP-1 to -6) and low affinity IGF binders (IGFBP-related proteins (IGFBP-rPs)). The IGFBPs modulate IGF bioactivity, and bind with differential affinities to IGFs in serum and various biological fluids (Kelley et al. 1996, Rajaram et al. 1997). In addition, recent evidence suggests that some IGFBPs may have direct receptor-mediated effects independent of IGFs (Oh et al. 1993). IGFBP-3, for example, has been demonstrated to be an important mediator of other growth inhibitory agents, such as retinoic acid (Gucev et al. 1996), vitamin D (Colston et al. 1998), TGF- $\beta$ (Oh et al. 1995, Gucev et al. 1996, Rajah et al. 1997), anti-estrogens (Huynh et al. 1996), tumor necrosis factor- $\alpha$ (Rozen et al. 1998) and p53 (Buckbinder et al. 1995), independently of the IGF signaling system. Furthermore, the importance of IGF-independent biological effects of the IGFBP superfamily, such as IGFBP-3 (Oh et al. 1993), IGFBP-rP1 (Burger et al. 1998) and -rP2 (Hishikawa et al. 1999) on cell replication has been demonstrated in human breast cancer cell systems.

In this study, we have investigated the effects of sodium butyrate $(\mathrm{NaB})$ on members of the IGFBP superfamily in human mammary epithelial cells, using estrogenresponsive (MCF-7) and estrogen-non-responsive (Hs578T) breast cancer cells, and normal human mammary epithelial (HMEC) cells. We report here that $\mathrm{NaB}$ upregulates IGFBP-3 and IGFBP-rP2 mRNA and protein in mammary epithelial cells.

\section{Materials and Methods}

\section{Materials}

$\mathrm{NaB}$, TSA, BSA and $0 \cdot 4 \%$ trypan blue solution were purchased from Sigma Chemical Co. (St Louis, MO, USA). ${ }^{125}$ I-labeled IGF-I was kindly provided by Diagnostic Systems Laboratories (Webster, TX, USA). Polyclonal anti-IGFBP-3, anti-IGFBP-rP1, antiIGFBP-rP2 and anti-HEC1 (specific for both human IGFBP-2 and -3) antisera were generated as previously described (Rosenfeld et al. 1990, Oh et al. 1993, Wilson et al. 1997, Yang et al. 1998). Polyclonal anti-IGFBP-5 antibody was purchased from Austral Biologicals (San Ramon, CA, USA). Polyclonal anti-acetyl-lysine, antiacetylated histone $\mathrm{H} 3$ and anti-acetylated histone $\mathrm{H} 4$ antibodies were purchased from Upstate Biotechnology (Lake Placid, NY, USA). Polyclonal anti-poly(ADP- ribose)polymerase (PARP) antibody was purchased from Santa Cruz Biotechnology (Santa Cruz, CA, USA). Monoclonal antibodies, anti-p21 ${ }^{\text {Waf1/Cip1, }}$ anti-p16 ${ }^{\text {INK4 }}$ and anti-p2 $7^{\text {Kip1 }}$ were purchased from Transducion Laboratories (Lexington, KY, USA), PharMingen (San Diego, CA, USA) and Calbiochem (Cambridge, MA, USA) respectively.

\section{Cell culture}

Hs578T estrogen-non-responsive human breast cancer cells and MCF-7 estrogen-responsive human breast cancer cells were purchased from ATCC (Manassas, VA, USA). Both cell lines were maintained in DMEM supplemented with $4.5 \mathrm{~g} / 1$ glucose, $110 \mathrm{mg} / 1$ sodium pyruvate, and $10 \%$ fetal bovine serum. HMEC (normal human mammary epithelial cells) were purchased from Clonetics (San Diego, CA, USA), and maintained in mammary epithelium basal medium (MEBM) with growth supplements (bovine pituitary extract (BPE), human epidermal growth factor, insulin, hydrocortisone, gentamicin and amphotericin-B) as directed by the manufacturer.

\section{$\left[{ }^{3}\right.$ H]thymidine incorporation assay}

Cells were seeded into $24-w e l l$ dishes at $37^{\circ} \mathrm{C}$ in $5 \% \mathrm{CO}_{2}$. At $90 \%$ confluence, cells were placed in serum-free media for $12 \mathrm{~h}$, then treated as indicated in the text. After $22 \mathrm{~h}$, $0 \cdot 1 \mu \mathrm{Ci}\left[{ }^{3} \mathrm{H}\right]$ thymidine (NEN, Boston, MA, USA) in a volume of $25 \mu \mathrm{l}$ PBS was added to each well, and the plate was incubated for $4 \mathrm{~h}$ at $37^{\circ} \mathrm{C}$. Cells were washed with cold PBS twice, treated with 10\% trichloroacetic acid (TCA) for $10 \mathrm{~min}$ at $-20{ }^{\circ} \mathrm{C}$, washed with $10 \%$ TCA followed by $95 \%$ ethanol, and lysed with $400 \mu \mathrm{l} 0 \cdot 25 \mathrm{~N}$ $\mathrm{NaOH}$ per well. Cell lysates (CL) from each well were transferred to scintillant vials, then $10 \mathrm{ml}$ scintillation fluid with $100 \mu \mathrm{l} 2 \mathrm{~N} \mathrm{HCl}$ were added to the vials, and the radioactivity was measured in a scintillation counter.

\section{MTS assay}

Hs578T cells were seeded into 96-well plates. At $80 \%$ confluence, they were incubated for $12 \mathrm{~h}$ in serum-free DMEM, then treated with various concentrations of $\mathrm{NaB}$ as indicated in the text in serum-free media. After a further incubation of 1-4 days, the MTS reagent (Promega Co., Madison, WI, USA) was added in the ratio recommended by the manufacturer. At 15 min intervals, the absorbance of the formazan product at $490 \mathrm{~nm}$ was read with a plate reader (Spectra Shell Reader; SLT Labinstruments $\mathrm{GmbH}$, Austria). On the same plate, cells were dispensed at the differential confluency. These cells were left untreated in serum-free media, and then the MTS reagent was added at the same time as to the butyrate-treated wells. After the reading, cells were trypsinized, then the cell number was counted with a 
hemacytometer. Using this method, a linear correlation was obtained between direct cell counts from $1 \times 10^{3}$ to $1 \times 10^{4}$ per well and the absorbance $(r=0 \cdot 85, n=70)$ (data not shown). The experiment was repeated three times in conditions where the starting untreated control cell number was $8 \times 10^{3}$ per well, and the absorbance at $490 \mathrm{~nm}$ read at $45 \mathrm{~min}$ after adding the MTS reagent to the wells was $\sim 0 \cdot 8$.

\section{Quantitation of apoptosis}

To quantitate apoptotic cell death, the Cell Death Detection ELISAPLUS kit (Roche Molecular Biochemicals, Mannheim, Germany), which measures cytoplasmic histone-bound DNA fragments produced during apoptotic DNA fragmentation, was used (Mandal \& Kumar 1996). Hs578T cells were seeded into a 96-well plate at $80 \%$ confluence, they were incubated for $12 \mathrm{~h}$ in serum-free DMEM, then treated with various concentrations of $\mathrm{NaB}$ in serum-free media. After $72 \mathrm{~h}$, cytoplasmic extracts were made from attached cells by adding $100 \mu \mathrm{l}$ lysis buffer to $5 \times 10^{3}$ cells per well. Supernatant $(20 \mu \mathrm{l}$ from $100 \mu \mathrm{l})$ was analyzed in the ELISA, as directed by the manufacturer's protocol. Briefly, the samples were placed into streptavidin-coated multi-well plates, a mixture of anti-histone-biotin and anti-DNA-peroxidase was added and incubated. The ELISA was developed with peroxidase substrate, and the absorbance at $405 \mathrm{~nm}$ was measured against $490 \mathrm{~nm}$ as a reference wavelength. The experiment was performed from duplicate samples for each data point generated, and was repeated twice independently.

\section{Preparation of conditioned media (CM) and $C L$}

Cells were seeded in 12-well plates. At 95\% confluence, they were incubated for $12 \mathrm{~h}$ in serum-free DMEM (Hs578T and MCF-7) or supplement-free MEBM with added BPE (HMEC), then treated as indicated in the text in serum- or supplement-free media. CM samples were collected after $72 \mathrm{~h}$ and centrifuged at $1000 \mathrm{~g}$ for $10 \mathrm{~min}$ to remove debris. The harvested CM from duplicate wells within each experiment were pooled and stored at $-20{ }^{\circ} \mathrm{C}$ until assay. Proteins in $40 \mu \mathrm{l} \mathrm{CM}$ per lane were examined by Western immunoblot or Western ligand blot under non-reducing conditions.

CL samples were harvested at $24 \mathrm{~h}$ post-treatment by washing with PBS, and then adding $150 \mu \mathrm{l}$ cold RIPA lysis buffer (20 mM Tris, pH 8.0, $150 \mathrm{mM} \mathrm{NaCl}, 1 \%$ NP-40, $0 \cdot 5 \%$ NaDOC, $0 \cdot 1 \%$ SDS) plus protease inhibitors cocktail (Roche Molecular Biochemicals) directly to each well. Plates were rocked for $30 \mathrm{~min}$ at $4{ }^{\circ} \mathrm{C}$, and the lysates were collected and centrifuged at $10000 \boldsymbol{g}$ for $10 \mathrm{~min}$ at $4{ }^{\circ} \mathrm{C}$. The supernatants from duplicate wells within each experiment were pooled and stored at $-20{ }^{\circ} \mathrm{C}$ until assay. Total protein concentration was determined for each sample using DC Protein Assay Reagent (Bio-Rad, Hercules, CA, USA), and $20 \mu \mathrm{g}$ total protein per sample were examined by Western immunoblot under reducing conditions.

\section{Western ligand blot analysis}

Proteins from CM samples were size-fractionated by $12 \%$ SDS-PAGE under non-reducing conditions and electroblotted onto nitrocellulose filters (Hybond; Amersham Pharmacia Biotech, Piscataway, NJ, USA). Filters were washed in $3 \% \mathrm{NP}-40 / \mathrm{ddH}_{2} \mathrm{O}$ for 30 min, blocked with 1\% BSA/TBS-T (20 mM Tris-HCl, pH 7.6, $150 \mathrm{mM}$ $\mathrm{NaCl}, 0 \cdot 1 \%$ Tween-20) for $2 \mathrm{~h}$, and incubated overnight with $2 \cdot 0 \times 10^{6}$ c.p.m. ${ }^{125}$ I-labeled IGF-I. The membranes were washed, dried and exposed to film (Kodak BioMax MS, Eastman Kodak Co., Rochester, NY, USA) for 12-18 h.

\section{Western immunoblot analysis}

For IGFBP-3, IGFBP-rP1 and IGFBP-rP2 detection, CM samples were separated on non-reducing 12 or $15 \%$ SDS-PAGE. For $\mathrm{p} 21^{\text {Waf1/Cip } 1}$ detection, CL samples were separated on reducing 15\% SDS-PAGE. Proteins were electrotransferred onto nitrocellulose, and membranes were blocked with $5 \%$ non-fat dry milk/TBS-T for $1 \mathrm{~h}$ at room temperature, then incubated in 1:3000 dilution of primary antibody at $4{ }^{\circ} \mathrm{C}$ overnight. Immunoreactive proteins were detected using enhanced chemiluminescence (NEN, Boston, MA, USA).

\section{Total RNA isolation and Northern blot analysis}

Cells were grown in 6-well plates until 95\% confluent. Cells were then incubated in serum-free media for $12 \mathrm{~h}$, then treated for $18 \mathrm{~h}$ in serum- or supplement-free media as indicated in the text. Total RNA was isolated from duplicate wells, using the RNeasy Kit (Qiagen, Valencia, CA, USA), and $5 \mu \mathrm{g}$ total RNA per sample were separated on a $1 \%$ formaldehyde agarose gel and transferred to nylon membranes (GeneScreenPlus; NEN). Membranes were stained with $0.02 \%$ methylene blue in $0.3 \mathrm{M} \mathrm{NaOAc}, \mathrm{pH}$ $5 \cdot 5$, and $18 \mathrm{~S}$ and $28 \mathrm{~S}$ rRNA bands were used as internal controls to adjust for sample loading. The blot was then hybridized at $65^{\circ} \mathrm{C}$ with full length cDNA probes random-labeled with $\left[{ }^{32} \mathrm{P}\right] \mathrm{dCTP}$ (Prime-It II; Stratagene, Cedar Creek, TX, USA), washed and autoradiographed.

\section{Densitometric analysis}

To quantitate the relative induction after Western blot analyses or Northern blot analyses, densitometric measurement was performed by using a GS-700 imaging densitometer with Multi-Analyst software (Bio-Rad). 

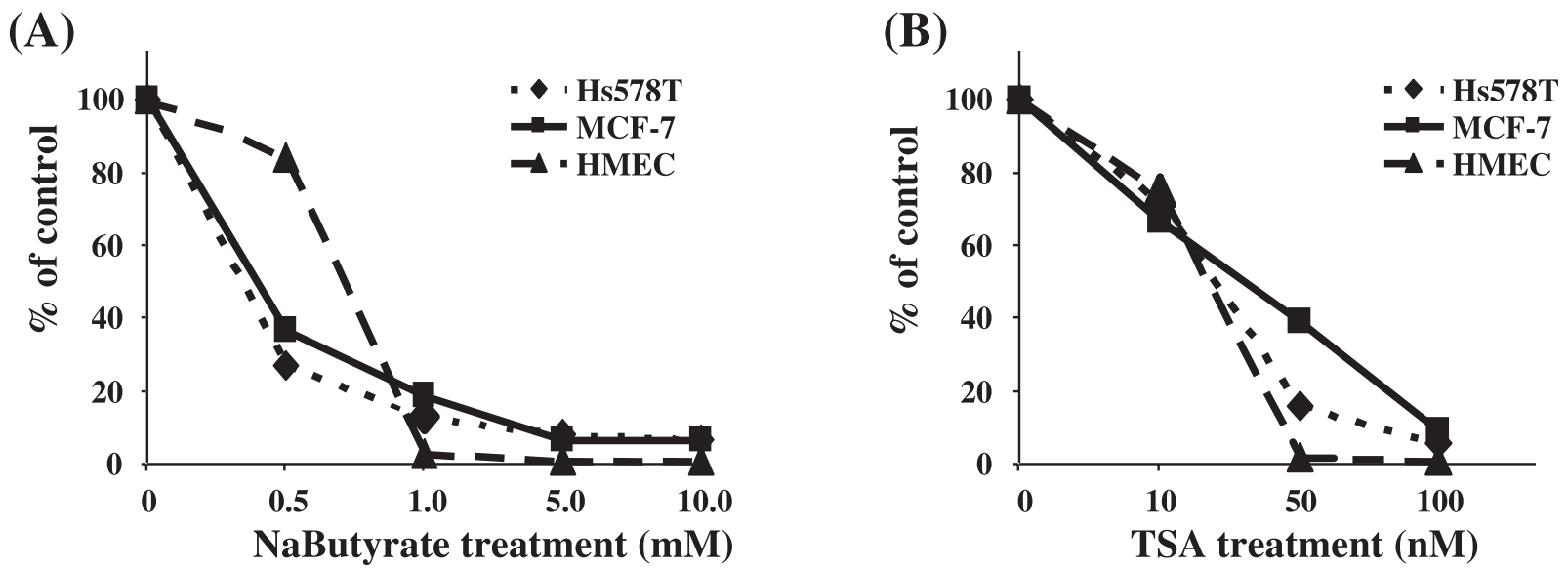

Figure 1 Effect of $\mathrm{NaB}(\mathrm{A})$ and TSA (B) on DNA synthesis in Hs578T, MCF-7 and HMEC cells. Serum-starved cells (85-90\% confluent) were incubated in basal medium for $22 \mathrm{~h}$ in the absence or presence of various concentrations of $\mathrm{NaB}$ or TSA as indicated. $\left[{ }^{3} \mathrm{H}\right]$ Thymidine was added, and the incubation was continued for another $4 \mathrm{~h}$. The incorporation of $\left[{ }^{3} \mathrm{H}\right]$ thymidine was determined relative to control cells incubated without the addition of these reagents. Results represent the average of two independent experiments each performed in triplicate.

\section{Results}

$\mathrm{NaB}$ treatment inhibits DNA synthesis and causes histone hyperaceylation in human mammary epithelial cells

Since it has been demonstrated that treatment of $\mathrm{NaB}$ resulted in growth inhibition in a variety of cell systems in vitro, we first examined the effect of $\mathrm{NaB}$ on DNA synthesis in normal (HMEC) and cancerous (Hs578T, MCF-7) human mammary epithelial cells, using the $\left[{ }^{3} \mathrm{H}\right]$ thymidine incorporation assay. $\mathrm{NaB}$ suppressed DNA synthesis in both cancerous and non-cancerous human mammary epithelial cells in a dose-dependent manner, with $90-100 \%$ inhibition at $\mathrm{NaB}$ concentrations of $5 \mathrm{mM}$ (Fig. 1A). One major function of $\mathrm{NaB}$ is inhibition of histone deacetylase activity, resulting in histone hyperacetylation. In order to determine whether $\mathrm{NaB}$-induced inhibition of DNA synthesis might be due to histone hyperacetylation, we treated the cells with TSA, a specific histone deacetylase inhibitor, and compared its effect on DNA synthesis. As shown in Fig. 1B, TSA also suppressed DNA synthesis, with 90-100\% inhibition at TSA concentrations of $100 \mathrm{nM}$ in these cells. This suggests that butyrate-induced suppression of DNA synthesis in these human mammary cells may involve histone hyperacetylation, as is shown by Western immunoblot with an anti-acetyl-lysine antibody (Fig. 2). The CL $24 \mathrm{~h}$ after treatment with $\mathrm{NaB}$ showed an increase of acetylated proteins in a dose-dependent manner, as indicated by the appearance of 11 and $16 \mathrm{kDa}$ bands, which were identified as $\mathrm{H} 4$ and $\mathrm{H} 3$ histones respectively by Western immunoblot with specific antibodies (data not shown). Histone hyperacetylation was similarly demonstrated by treatment with TSA (Fig. 2). Interestingly, only the $11 \mathrm{kDa}$ band was seen at concentrations over $100 \mathrm{nM}$.
Effects of $\mathrm{NaB}$ on reducing cell number and the induction of apoptosis in human mammary epithelial cells

As $\mathrm{NaB}$ inhibits DNA synthesis almost completely by $24 \mathrm{~h}$ treatment, cell viability over 4 days after $\mathrm{NaB}$ treatment in Hs578T cells was then studied. The MTS assay was used, as described in Materials and Methods, as a marker of relative viable cell number. A progressive reduction in cell number by MTS assay was observed from day 2 onwards using $10 \mathrm{mM} \mathrm{NaB}$, and from day 3 onwards after $5 \mathrm{mM}$ $\mathrm{NaB}$ treatment (Fig. 3). In parallel wells, when cell numbers were counted after trypsinizing by direct visualization using a hemacytometer, the attached cell numbers were reduced over the same time course and concentrations of $\mathrm{NaB}$ as was detected in the MTS assay above (data not shown). Using trypan blue exclusion during hemacytometer counting, when counted at the same time point, the same number of attached cells were shown to take up trypan blue in the NaB-treated wells compared with the control wells, throughout the full 4 days of the study (data not shown). This trypan blue staining pattern indicates that cell plasma membrane integrity was maintained in the attached cells after $\mathrm{NaB}$ treatment compared with the control.

As a reduction in viable cell number by $\mathrm{NaB}$ was occurring over time, the possibility that apoptosis was being induced by $\mathrm{NaB}$ in the mammary epithelial cells was then addressed. Two independent methods of analysis were used to detect apoptosis: first, nuclear enzyme cleavage, and secondly, DNA fragmentation. The nuclear enzyme PARP is proteolytically cleaved during apoptosis in vitro in many cell types, including breast cancer cells (Kaufmann et al. 1993). Figure 4A shows Western immunoblots with an anti-PARP antibody after treatment of Hs578T and MCF-7 cells with $\mathrm{NaB}$ followed by 

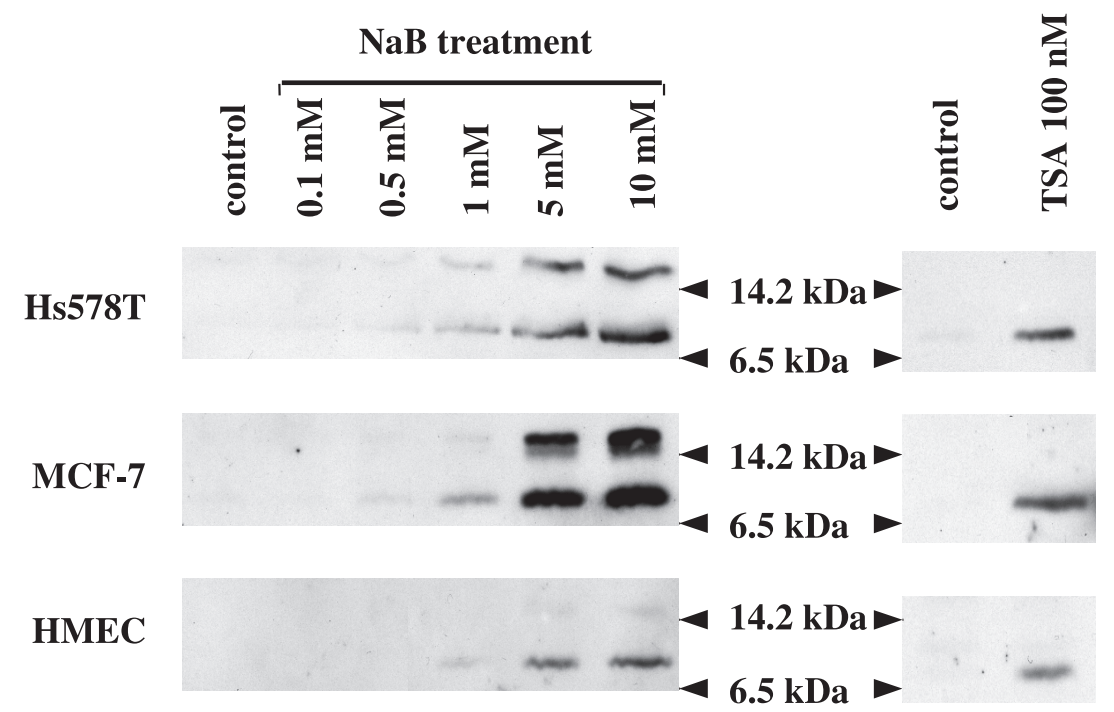

Figure 2 Effect of $\mathrm{NaB}$ on protein acetylation. Serum-starved cells were treated for $24 \mathrm{~h}$ with various concentrations of $\mathrm{NaB}$ as indicated. $\mathrm{CL}$ harvested from duplicate wells within each experiment were pooled, and $20 \mu \mathrm{g}$ protein per lane were loaded onto $15 \%$

SDS-PAGE under reducing conditions. Gels were immunoblotted with an anti-acetyl-lysine antibody as described in Materials and Methods. The immunoblots of $\mathrm{CL}$ treated with $100 \mathrm{nM}$ TSA are shown on the right. Molecular mass markers are also shown. The results are representative of two independent experiments.

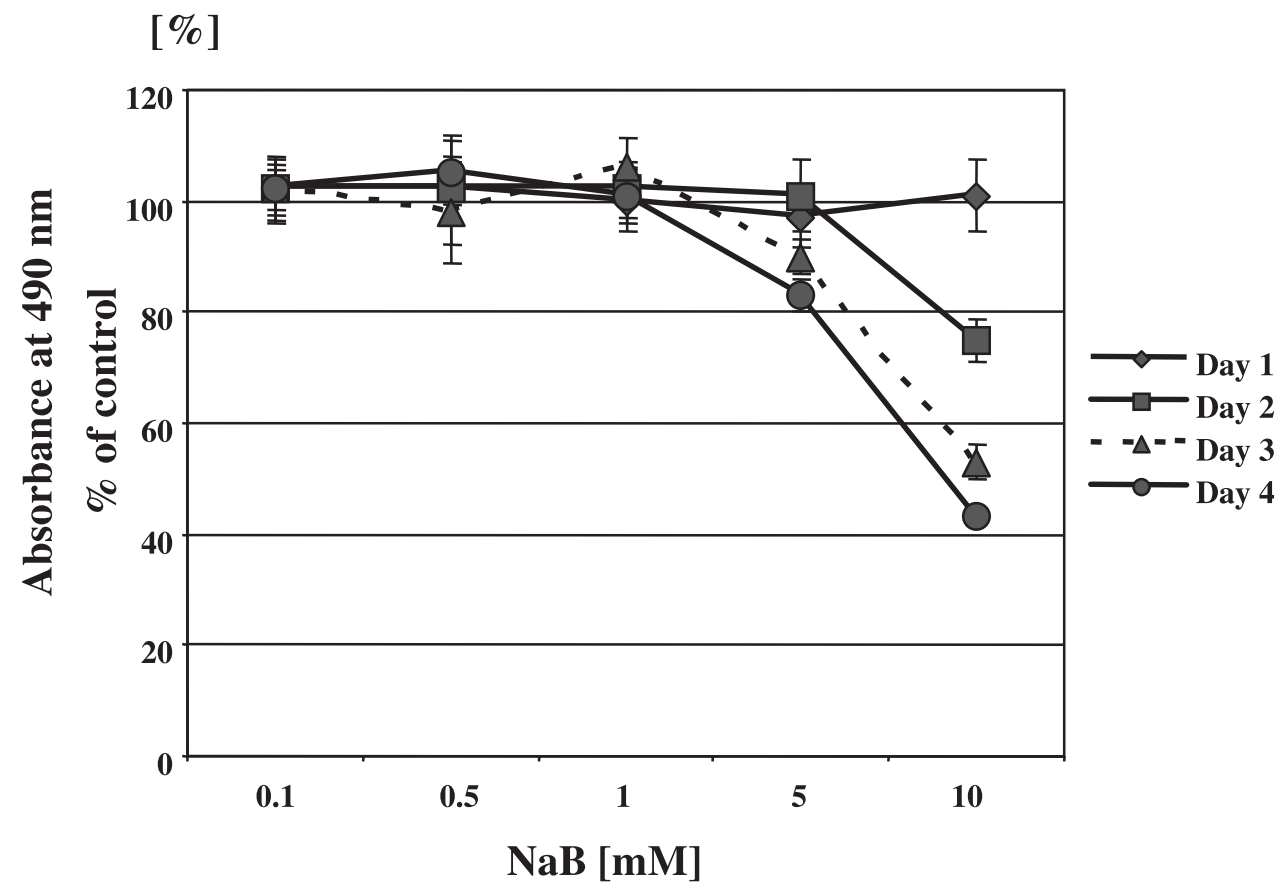

Figure 3 Growth inhibition by NaB. Hs578T cells were seeded into 96-well plates, then serum-starved cells were treated with various concentrations of $\mathrm{NaB}$ as indicated. On subsequent days, cell proliferation was measured using the MTS assay. A dose-response effect with added NaB is seen over 4 days. Results are expressed in absorbance readings at $490 \mathrm{~nm}$ as percent of the untreated controls \pm S.E. $(n=16)$. 
(A)
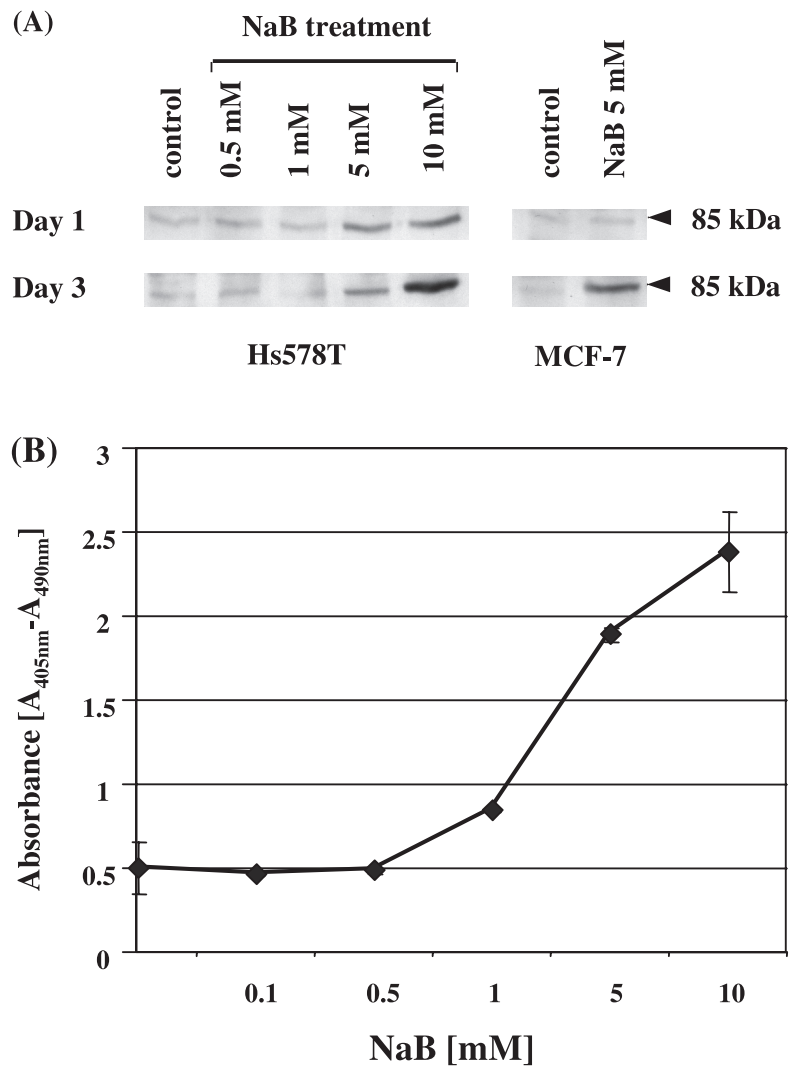

Figure 4 Effect of $\mathrm{NaB}$ on apoptosis. (A) Immunoblot analysis of PARP in Hs578T and MCF-7 CL obtained during treatment with $\mathrm{NaB}$ (day 1 and day 3). The $85 \mathrm{kDa}$ fragment characteristic of apoptosis is shown. The data shown are representative of two independent experiments. (B) Induction of apoptosis in Hs578T cells treated with increasing doses $(0-10 \mathrm{mM})$ of $\mathrm{NaB}$ for $72 \mathrm{~h}$. Cytoplasmic extracts were prepared from attached cells, and apoptotic cell death was quantitated by ELISA measuring cytoplasmic histone-bound DNA complexes characteristic of apoptosis, as described in Materials and Methods. Results are expressed as mean absorbance \pm S.D. of two independent experiments performed in duplicate $(n=4)$.

analysis of CL. The $\sim 85 \mathrm{kDa}$ carboxy-terminal fragment of PARP detected by Western immunoblotting is indicative of apoptosis occurring in the lysates sampled (Kaufmann et al. 1993, Lazebnik et al. 1994). In Hs578T cells, some induction of the fragment was already observed by day 1 at concentrations of $5 \mathrm{mM} \mathrm{NaB}$ and above, and was more marked in the day 3 lysates, particularly after $10 \mathrm{mM} \mathrm{NaB}$. Detectable increases in the PARP fragment were also seen in the day $3 \mathrm{CL}$ of MCF-7 cells (Fig. 4A).

To verify and more accurately quantitate the apoptosis induced by $\mathrm{NaB}$, an ELISA kit that detects histoneassociated DNA fragments (mono- and oligonucleosomes) in the cytoplasmic fraction of CL was used, as described in Materials and Methods. In the Hs578T cytoplasmic extracts from attached cells studied at 3 days post-treatment, $\mathrm{NaB}$ induced apoptosis in a dosedependent manner (Fig. 4B). This sensitive assay demonstrated apoptotic effects initially commencing at $1 \mathrm{mM}$ $\mathrm{NaB}$. Taken together, the two methods of measuring apoptosis show that $\mathrm{NaB}$ induces apoptosis in the cells studied, in a more delayed time course compared with the earlier effects on $\left[{ }^{3} \mathrm{H}\right]$ thymidine incorporation. The apoptosis induced by $\mathrm{NaB}$ would be expected to reduce the viable cell number, which was observed, as described earlier.

$\mathrm{NaB}$ upregulates expression of $p 21^{\text {Waf1/Cip } 1} m R N A$ and protein levels in human mammary epithelial cells

As the major mechanism for butyrate-induced growth inhibition in various cell systems is known to be through

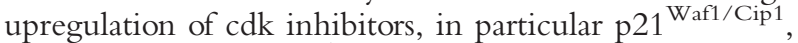
the induction of $\mathrm{p} 21^{\mathrm{Waf1} / \mathrm{Cip} 1}$ in mammary epithelial cells was next investigated. Figure $5 \mathrm{~A}$ is a Northern blot of p21 Waf1/Cip1 from Hs578T, MCF-7 and HMEC cells treated with or without $\mathrm{NaB}$. p2 $1^{\text {Waf1/Cip1 }}$ mRNA expression was upregulated in all three cell lines, and was most marked in Hs578T cells. As shown in Fig. 5B, an upregulation of $\mathrm{p} 21^{\mathrm{Waf} 1 / \mathrm{Cip} 1}$ protein levels occurred in these cells, with the greatest increase in $\mathrm{p} 21^{\mathrm{Waf} 1 / \mathrm{Cip} 1}$ observed in Hs578T cells, which parallels the mRNA data. As the degree of induction was different between Hs578T cells and the other two cell lines, the $\mathrm{NaB}$ effect on cdk inhibitors $\mathrm{p} 27^{\mathrm{Kip} 1}$ and $\mathrm{p} 16^{\mathrm{INK} 4}$ was further investigated. A distinct upregulation of $\mathrm{p} 27^{\mathrm{Kip} 1}$ by $\mathrm{NaB}$ treatment (a 2.5-fold increase at $5 \mathrm{mM}$ treatment) was reproducibly seen in HMEC cells, but not in the cancerous cell lines (Fig. 5B). We did not detect $\mathrm{p} 16^{\text {INK } 4}$ in Hs578T and MCF-7 cells, and only a slight induction of this protein was seen in HMEC cells. Taken together, these data suggest that differential $\mathrm{cdk}$ inhibitors are induced by $\mathrm{NaB}$ treatment, in a cell-type-dependent manner.

Butyrate upregulates IGFBP-3 $m R N A$ and protein levels in cancerous, but not in non-cancerous mammary cells

To investigate any correlation between the effect of $\mathrm{NaB}$ and the regulation of IGFBP system, we first examined IGFBP-3, a known growth suppressor in human mammary cells. Northern blotting was firstly performed to measure steady-state mRNA levels. Figure 6A shows the time-course effect of $\mathrm{NaB}$ treatment on steady-state levels of IGFBP-3 mRNA in Hs578T cells. $\mathrm{NaB}$ induced the expression of IGFBP-3 mRNA in a time-dependent manner, with increases first detectable at $6 \mathrm{~h}$ after treatment, and with a $2 \cdot 5$-fold increase after treating cells with $5 \mathrm{mM} \mathrm{NaB}$ for $24 \mathrm{~h}$, whereas in the non-cancerous HMEC cells, only a slight induction $(<1 \cdot 2$-fold $)$ was observed (Fig. 6B). In MCF-7 cells, IGFBP-3 mRNA was not detected in these analyses. 

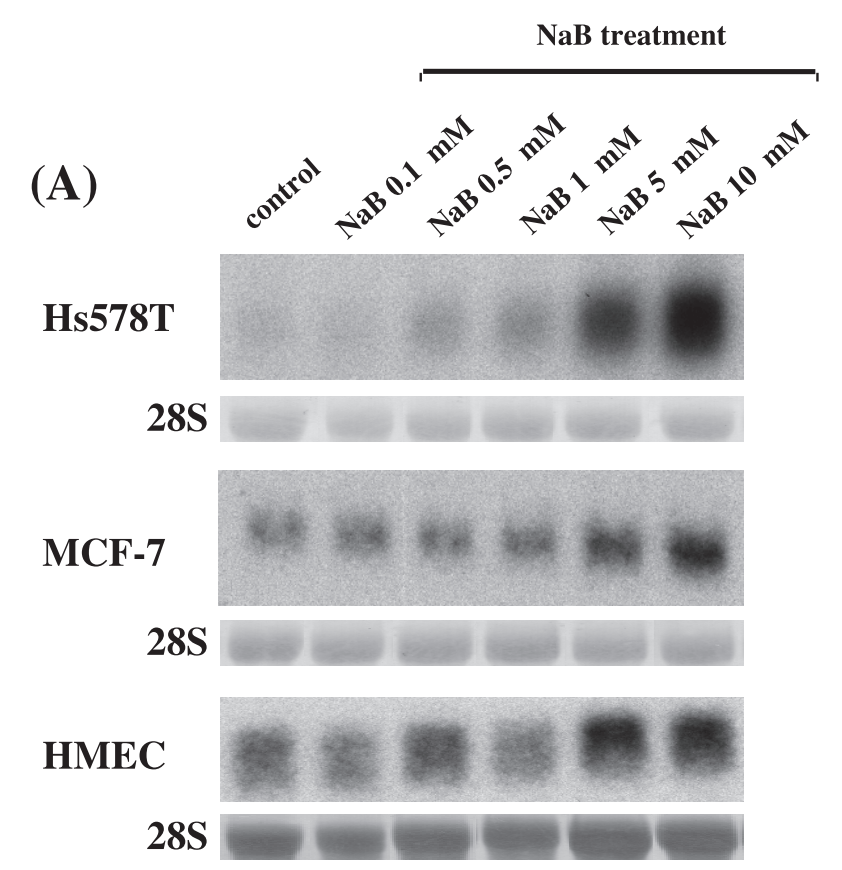

$$
\text { p21 }{ }^{\text {Waf1/Cip1 }} \operatorname{mRNA}(2.2 \mathrm{~kb})
$$

(B)

$$
\begin{aligned}
& \text { p21 }{ }^{\text {Waf1/Cip1 }} \text { protein } \\
& \text { p27 } \\
& \text { p161 } \\
&
\end{aligned}
$$

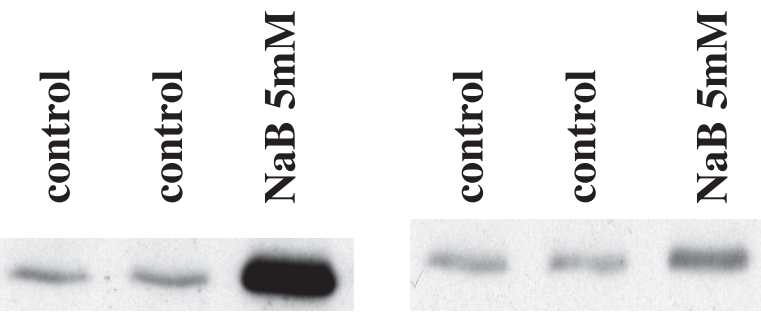

\section{Hs578T}
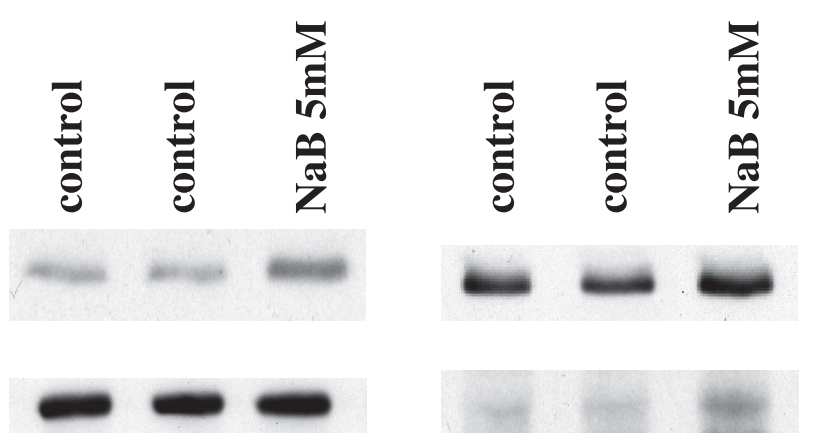

HMEC

Figure 5 Effect of $\mathrm{NaB}$ on expression of $\mathrm{p} 21^{\text {Waf1/Cip } 1}$ mRNA (A), and protein of p21 Waf1/Cip1 1 p2 $7^{\text {Kip } 1}$ and p16 ${ }^{\text {INK4 }}$ (B). (A) Representative Northern blots. Serum-starved cells were treated for $18 \mathrm{~h}$ with various concentrations of $\mathrm{NaB}$ as indicated. Total RNA was harvested, and

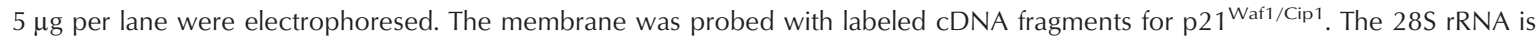
presented as an indicator of loading. The data shown are representative of at least three separate experiments. (B) Representative Western immunoblots. Twenty micrograms total protein from whole CL obtained at $24 \mathrm{~h}$ post-treatment per lane were loaded onto $15 \% \mathrm{SDS}$-PAGE under reducing conditions, and immunoblotted with anti-p2 $1^{\text {Waf1/Cip } 1}$, anti-p2 $7^{\text {Kip } 1}$ and anti-p16 ${ }^{\text {INK } 4}$, as indicated in Materials and Methods. Two sets of untreated controls were derived from different wells in the same culture plates. The data shown represent two separate experiments. p $16^{\text {INK4 }}$ was only detectable in the CL of HMEC cells.

The CM were then examined for changes in IGFBP-3 protein levels after $\mathrm{NaB}$ treatment. In order to ascertain a suitable time point to collect CM samples, the time-course induction of media IGFBP-3 protein in Hs578T cells was studied by Western ligand blot analysis, using ${ }^{125}$ I-labeled IGF-I as the ligand, as described in Materials and Methods. The IGFBP-3 level in the CM was detectably increased at $24 \mathrm{~h}$, even after $1 \mathrm{mM} \mathrm{NaB}$, was further increased at $48 \mathrm{~h}$, 
(A)
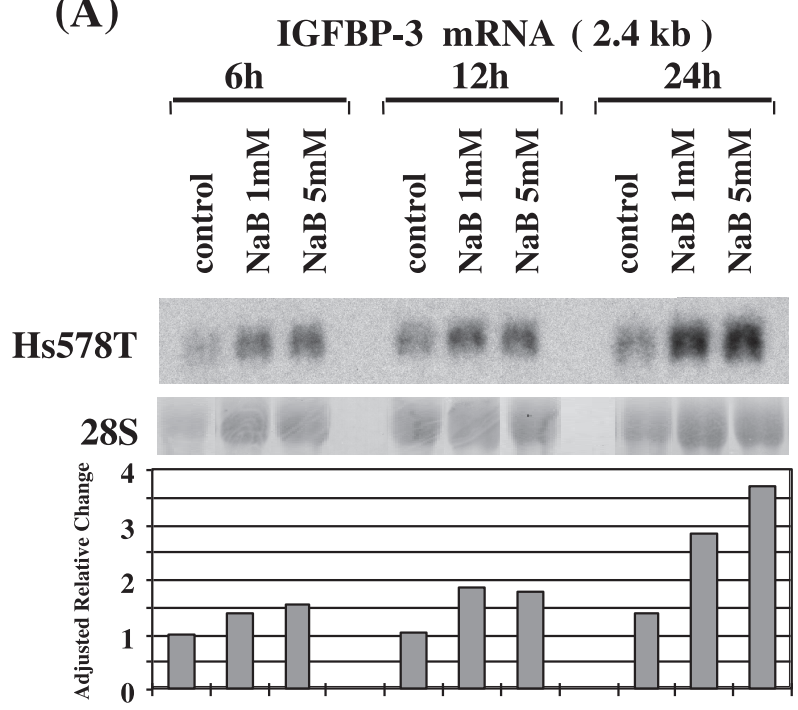

Densitometric Analysis

(B)

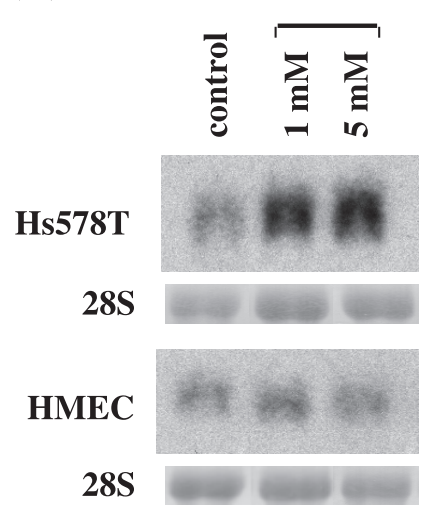

IGFBP-3 mRNA ( $2.4 \mathrm{~kb})$

Figure 6 Northern blot analysis of the effect of $\mathrm{NaB}$ on the expression of IGFBP-3 mRNA. Total RNA was harvested, and $5 \mu \mathrm{g}$ per lane were electrophoresed. The membrane was subsequently probed with labeled cDNA fragments of IGFBP-3. (A) Time-course expression of IGFBP-3 mRNA in Hs578T cells. Serum-starved cells were treated for 6,12 and $24 \mathrm{~h}$, with or without $\mathrm{NaB}$ as indicated. (B) Representative Northern blots for IGFBP-3 mRNA expression at $18 \mathrm{~h}$ (HMEC) and $24 \mathrm{~h}$ (Hs578T) post-treatment. 28S rRNA methylene blue membrane staining is presented as an indicator of equal loading. Densitometric analysis adjusted for $18 \mathrm{~S}$ and $28 \mathrm{~S}$ rRNA is also shown. Each result represents at least three independent experiments. In MCF-7 cells, IGFBP-3 mRNA was not detected in $10 \mu \mathrm{g}$ total RNA.

and peaked at $72 \mathrm{~h}$ following $\mathrm{NaB}$ treatment (Fig. 7A). Subsequently, CM at $72 \mathrm{~h}$ post-treatment were analyzed in further studies. As shown in Fig. 7B, various IGFBPs could be detected by the IGF ligand blot. The identity of these IGFBPs was confirmed by Western immunoblots using IGFBP-3, -2 and -5 specific antibodies, showing the $42-46 \mathrm{kDa}$ doublet bands to be IGFBP-3, the broad 29-36 kDa bands to contain IGFBP-2 and -5 , and the $24 \mathrm{kDa}$ band to be IGFBP-4 (data not shown). In HMEC cells, the Western ligand blot did not reveal an IGFBP-5 band, whereas the Western immunoblot with IGFBP-5 antibody revealed a low intensity band of the predicted molecular mass for IGFBP-5 (data not shown) (Adamo et al. 1992, Sheikh et al. 1992). IGFBP-3 protein levels were upregulated in both Hs578T $(2 \cdot 1$-fold over the control) and MCF-7 (12.6-fold over the control) cells, each after $5 \mathrm{mM} \mathrm{NaB}$ treatment (Fig. 7B). Further Western immunoblotting analyses demonstrated no detected IGFBP-3 fragments in all samples tested in these cells (data not shown). As the basal level of IGFBP-3 in MCF-7 cells was nearly undetectable, the induction of IGFBP-3 protein by $\mathrm{NaB}$ was more conspicuous in this cell line. In contrast, only slight upregulation of IGFBP-3 $(<1 \cdot 5$-fold) was observed in HMEC cells, mirroring the mRNA data (shown earlier in Fig. 6B). Levels of IGFBP$2 /-5$ and -4 showed no significant change up to $10 \mathrm{mM}$ $\mathrm{NaB}$ treatment, after accounting for effects of $\mathrm{NaB}$ on cell number (not shown). The effect of TSA treatment on IGFBP-3 protein levels by Western ligand blot and immunoblot was also studied. TSA treatment of both Hs578T and MCF-7 cells caused a dose-dependent increase in IGFBP-3 protein levels (not shown), suggesting that $\mathrm{NaB}$-induced upregulation of IGFBP-3 is, at least in part, through histone hyperacetylation. This effect was not seen in the HMEC cells (data not shown).

$\mathrm{NaB}$ upregulates IGFBP-rP2 $m R N A$ and protein expression in both cancerous and non-cancerous mammary cells

The induction of the low affinity IGF binders, especially IGFBP-rP2, was then investigated, as this protein also has recently been shown to have a growth suppressive effect in human mammary cells (Hishikawa et al. 1999). The effect of $\mathrm{NaB}$ treatment on IGFBP-rP2 mRNA expression was potent, particularly in Hs578T cells, where effects occurred with $0.5 \mathrm{mM} \mathrm{NaB}$. As seen in Fig. 8A, a 10-fold induction of IGFBP-rP2 by $5 \mathrm{mM} \mathrm{NaB}$ treatment was observed in Hs578T cells, whereas a maximal 2- to 3-fold induction occurred in HMEC cells. IGFBP-rP2 mRNA was not detected in MCF-7 cells.

Western immunoblot analysis against IGFBP-rP2 and $-\mathrm{rP} 1$ was then performed. As shown in Fig. 8B, NaB highly upregulated IGFBP-rP2 protein levels in all three cell lines in a dose-dependent manner ( $>10$-fold at $10 \mathrm{mM} \mathrm{NaB}$ over the control in all three cell lines). Increases in media IGFBP-rP2 were initially detectable within $24 \mathrm{~h}$, even after only $1 \mathrm{mM} \mathrm{NaB}$ (data not shown). In contrast to the effects on IGFBP-rP2, the IGFBP-rP1 band intensity was not increased by $\mathrm{NaB}$ treatment. The apparent reduction in IGFBP-rP1 by $\mathrm{NaB}$ treatment 


\section{(A)}

\section{IGFBP-3 protein secretion}
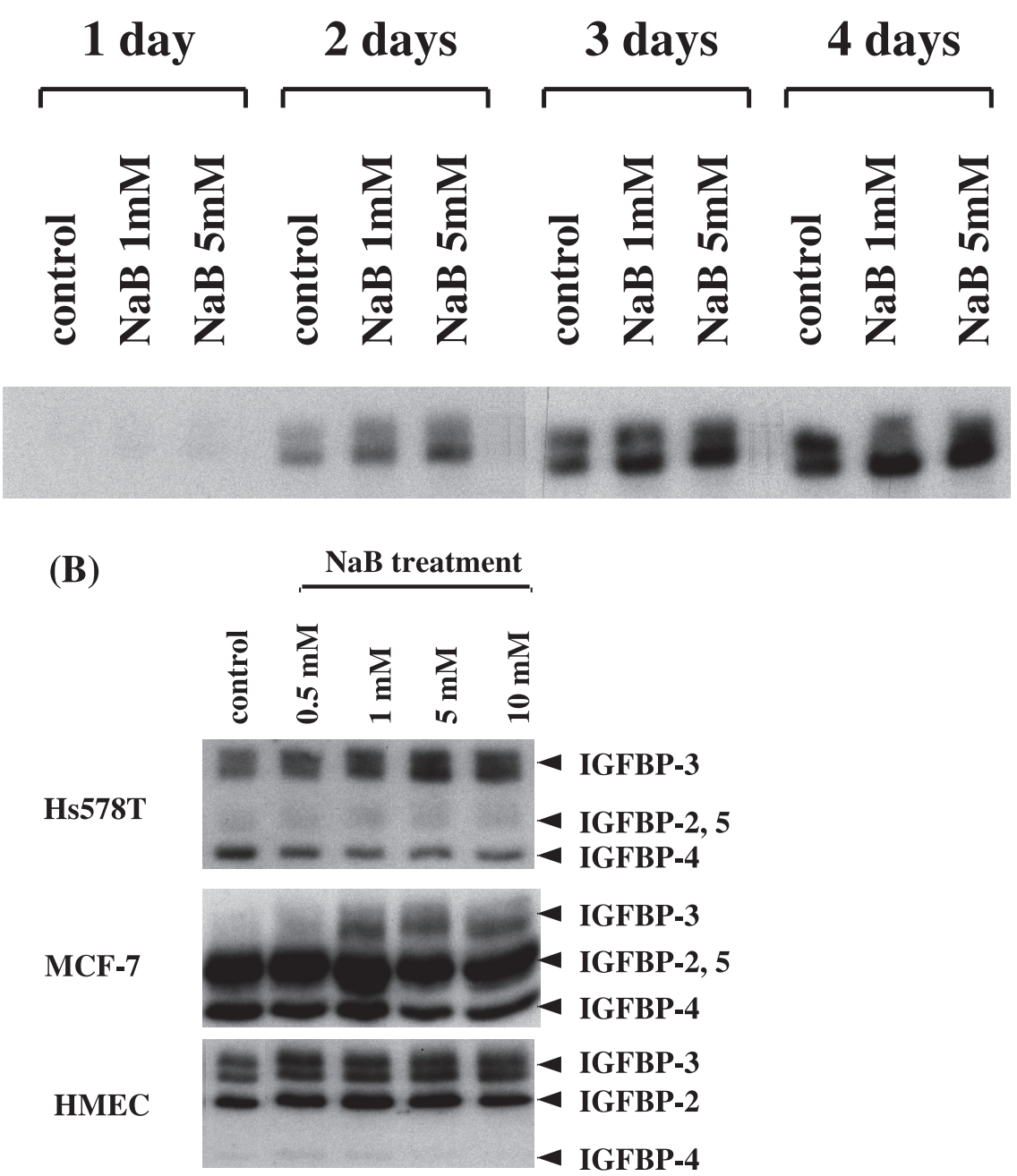

Figure 7 Effect of $\mathrm{NaB}$ on IGFBP production in Hs578T, MCF-7 and HMEC cells analyzed by Western ligand blotting. Serum-starved cells were treated with various concentrations of $\mathrm{NaB}$. CM harvested from duplicate wells within each experiment were pooled, size-fractionated using 12\% SDS-PAGE under non-reducing conditions, electroblotted onto nitrocellulose membranes, and treated with ${ }^{125}$ I-labeled IGF-I, as indicated in Materials and Methods. (A) Time-course expression of IGFBP-3 protein in Hs578T cells. Serum-starved cells were treated with or without NaB as indicated and Western ligand blot was performed over 4 days. (B) Representative Western ligand blots using $72 \mathrm{~h} \mathrm{CM}$ in Hs578T, MCF-7 and HMEC cells. The data shown were derived from at least three independent experiments.

compared with control, especially in Hs578T CM, was $52 \%$ on average using densitometric analysis at day 3 after $10 \mathrm{mM} \mathrm{NaB}$. This reduction in IGFBP-rP1 could be fully accounted for by considering the effects of $\mathrm{NaB}$ on cell number, as shown earlier in Fig. 3, where $40-50 \%$ of the cells are non-viable by this time of $\mathrm{NaB}$ treatment compared with control. IGFBP-rP1 was not detected in MCF-7 cells. These results show that IGFBP-rP2 mRNA and protein are specifically induced by $\mathrm{NaB}$ in both cancerous and non-cancerous breast epithelial cells.

\section{Discussion}

In this study, $\mathrm{NaB}$ effects in the human mammary cell system including cancerous and non-cancerous cells, was 
Hs578T

28S
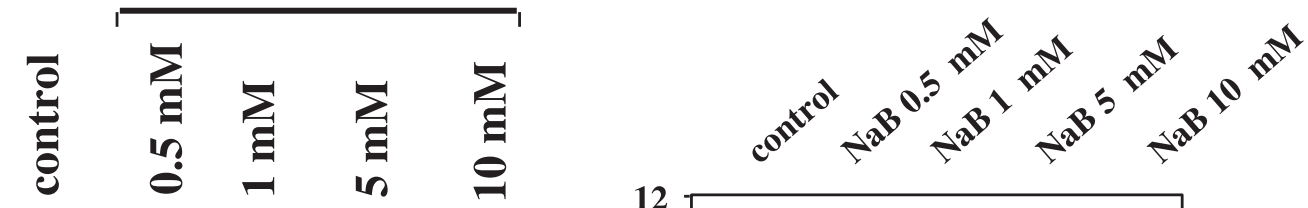

HMEC
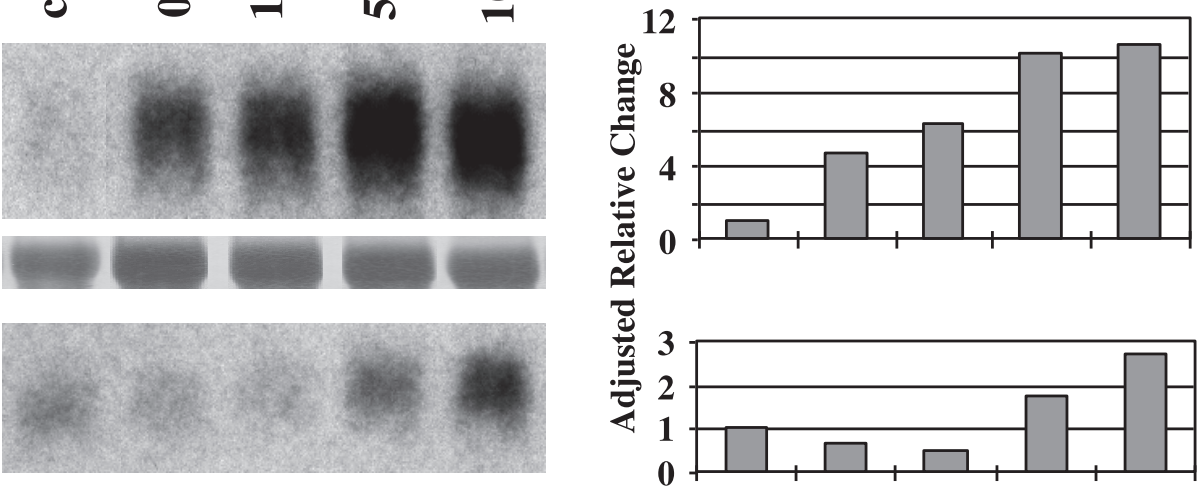

$28 S$

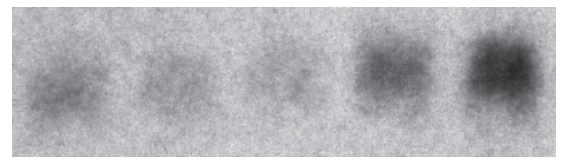

\section{Densitometric Analysis}

\section{IGFBP-rP2 mRNA ( 2.4 kb )}

(B)
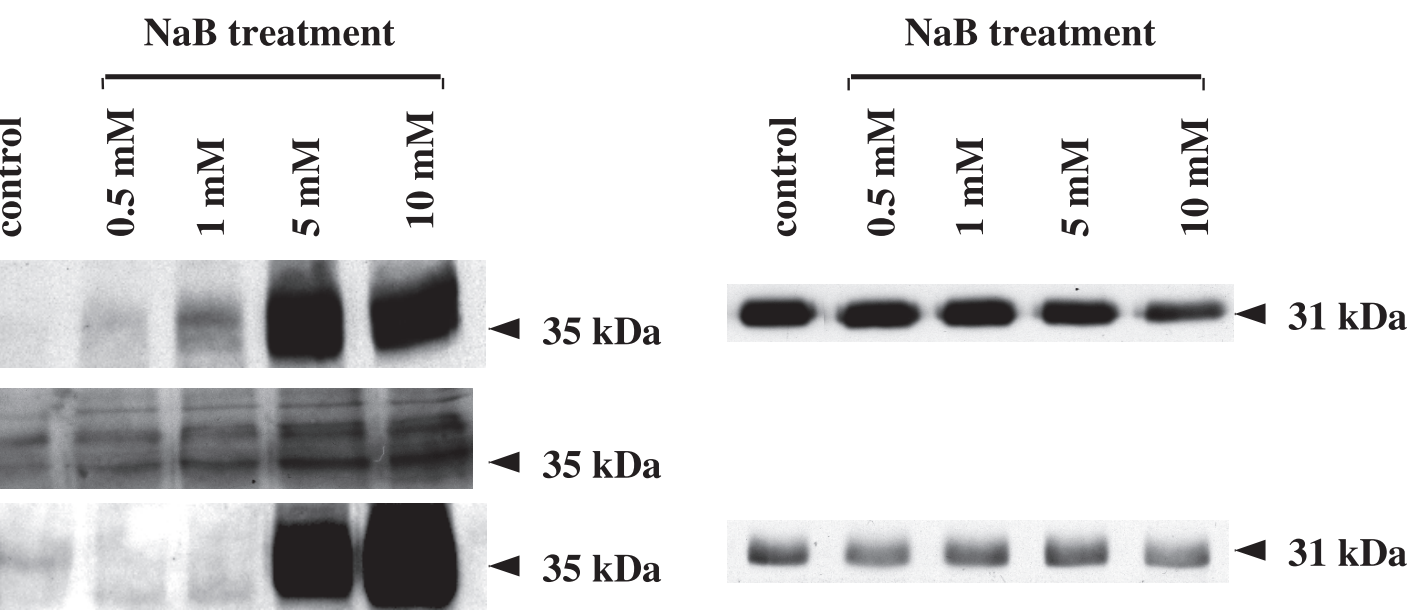

IGFBP-rP2

IGFBP-rP1

Figure 8 Effect of $\mathrm{NaB}$ on (A) IGFBP-rP2 mRNA expression, and (B) IGFBP-rP2 and -rP1 protein expression in Hs578T, MCF-7 and HMEC cells. (A) Representative Northern blots. Total RNA was harvested at $18 \mathrm{~h}$ post-treatment, and $5 \mu \mathrm{g}$ per lane were electrophoresed. The membrane was subsequently probed with labeled cDNA fragments of IGFBP-rP2. 28S rRNA methylene blue membrane staining is presented as an indicator of equal loading. Densitometric analysis adjusted for $18 \mathrm{~S}$ and $28 \mathrm{~S}$ rRNA is also shown. Each result represents two independent experiments. In MCF-7 cells, IGFBP-rP2 mRNA was not detected in $10 \mu \mathrm{g}$ total RNA. (B) Representative Western immunoblot analysis. Serum-starved cells were treated with various concentrations of $\mathrm{NaB}$ for $72 \mathrm{~h}$. CM harvested from duplicate wells within each experiment were pooled, size-fractionated using 12\% (for IGFBP-rP2) or 15\% (for IGFBP-rP1) SDS-PAGE under non-reducing conditions, electroblotted onto nitrocellulose membranes, and treated with appropriate antibodies, as indicated in Materials and Methods. IGFBP-rP1 was not detected in the CM of MCF-7 cells.

investigated, in order to obtain a greater understanding of the cellular mechanism of action of $\mathrm{NaB}$ in this cell type. $\mathrm{NaB}$ was found to cause an initial inhibition in new DNA synthesis, followed by apoptotic changes, and a reduction in viable cell number. Subsequently, the cdk inhibitors studied showed some cellular specificity in their 


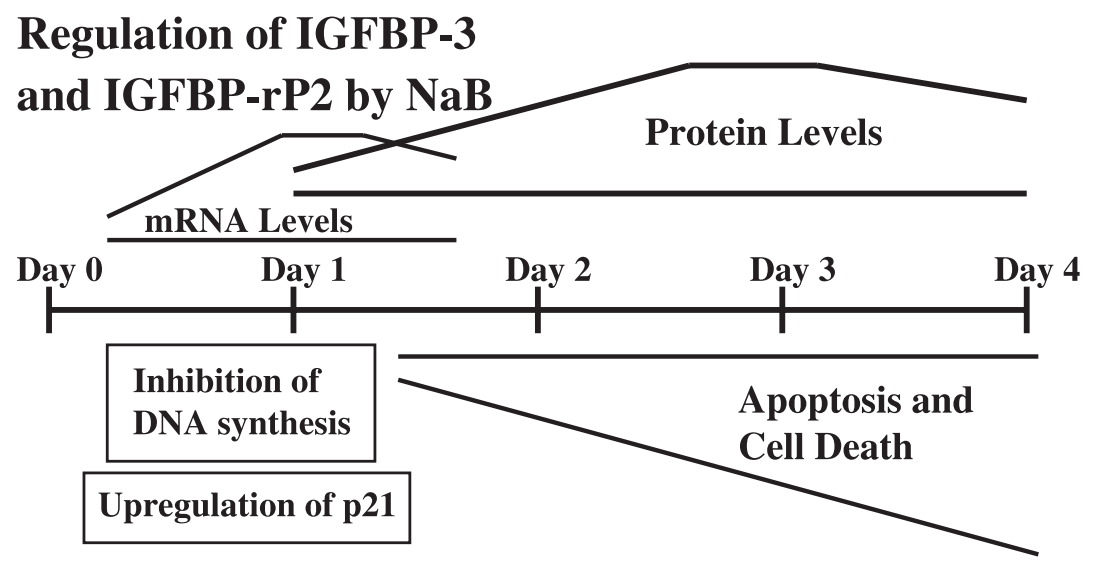

\section{Other Effects of $\mathrm{NaB}$}

Figure 9 Schematic diagram showing a summary of sequential effects of $\mathrm{NaB}$ in $\mathrm{Hs} 578 \mathrm{~T}$ cells observed in this study. The upregulation of IGFBP-3 and IGFBP-rP2 is shown above the time line and other effects of $\mathrm{NaB}$ including cell growth inhibition and cell death are shown below. For further description refer to the discussion in the text.

upregulation by $\mathrm{NaB}$. IGFBP superfamily members known to induce growth inhibition and apoptosis in breast epithelial cells were also upregulated by $\mathrm{NaB}$.

A schematic summary of our observations in Hs578T cells is shown in Fig. 9. We first studied the general effects of $\mathrm{NaB}$ on cell growth regulation. Butyrate induces diverse and reversible biological effects on cell differentiation, apoptosis and cell growth in vitro (Pouillart 1998). In colonic epithelial cells, butyrate is known to exert paradoxical effects, with induction of proliferation in normal cells and growth inhibition in neoplastic phenotypes (Hassig et al. 1997, Archer \& Hodin 1999). In the mammary system studied here, butyrate inhibits DNA synthesis in both normal and cancerous cells as measured by $\left[{ }^{3} \mathrm{H}\right]$ thymidine incorporation at $24 \mathrm{~h}$ after treatment. Also, as shown in Fig. 9, after $24 \mathrm{~h}$ of $\mathrm{NaB}$ treatment at concentrations over $1 \mathrm{mM}$, cell numbers became reduced in a dose- and time-dependent manner. This reduction in cell number was explained, at least in part, by $\mathrm{NaB}-$ induced apoptosis. The observed induction of apoptosis is consistent with previous reports of $\mathrm{NaB}$-induced apoptosis in other cell systems (Hague et al. 1993, Carducci et al. 1996, Coradini et al. 1997). In summary, $\mathrm{NaB}$ was found to induce both inhibition of DNA synthesis and programmed cell death, in Hs578T cells.

It is known that butyrate induces a variety of changes within the nucleus (Siavoshian et al. 1997, Schwartz et al. 1998), including histone hyperacetylation, especially of H3 and H4 (Archer \& Hodin 1999), and DNA methylation (de Haan et al. 1986). Previous studies indicate that the effect of butyrate and other histone deacetylase inhibitors on cells closely corresponds to the effects of $\mathrm{p} 21^{\text {Waf1/Cip } 1}$ expression in the regulation of G1 (Hunter \& Pines 1994), S (Ogryzko et al. 1997) and G2 (Coradini et al. 1997,
Lallemand et al. 1999) phases of the cell cycle (Hassig et al. 1997). The major mechanism for butyrate-induced cell cycle arrest is reported to be through upregulation of $\mathrm{p} 21^{\text {Waf1/Cip1 }}$ in various cell systems, including hepatocellular carcinoma cells (Yamamoto et al. 1998), colon cancer cells (Nakano et al. 1997, Siavoshian et al. 1997, Archer et al. 1998, Litvak et al. 1998), prostate cancer cells (Huang et al. 1999) and breast cancer cells (Lallemand et al. 1999). In contrast, Vaziri et al. (1998) demonstrated p21 Waf1/Cip1-independent G1 cell cycle arrest by butyrate in $3 \mathrm{~T} 3$ fibroblasts. In our present studies, the prominent induction of $\mathrm{p} 21^{\text {Waf1/Cip } 1}$ was observed in estrogen-nonresponsive Hs578T cancer cells, whereas modest induction was observed in estrogen-responsive MCF-7 cancer cells and non-cancerous HMEC cells. Interestingly, butyrate upregulated $\mathrm{p} 27^{\mathrm{Kip} 1}$ expression only in HMEC cells. The p16 $6^{\text {INK4 }}$ protein was detected only in HMEC cells and no further regulation was observed after butyrate treatment. Taken together, these data imply that the biological function of butyrate is mediated through more than one mechanism, even in butyrate-induced cell cycle arrest, suggesting that butyrate possesses multifunctional mechanisms of action.

This is the first demonstration that butyrate upregulates members of the IGFBP superfamily in human mammary cells. One previous report showed that only IGFBP-2 was upregulated by butyrate in colon cancer cells (Nishimura $e t$ al. 1998). In contrast, our studies demonstrate that among the six IGFBPs and IGFBP-rP-1 and -2, only IGFBP-3 and IGFBP-rP2 are upregulated by butyrate in cancerous and non-cancerous mammary epithelial cells. Recent evidence has suggested that, in addition to modulating the access of IGFs to their receptors, IGFBP-3 has the ability to suppress proliferation in various cell systems, including 
human breast cancer cells, working through IGFindependent mechanisms (Valentinis et al. 1995, Oh 1998). Further studies have demonstrated that IGFBP-3 directly induces apoptosis through an IGF-independent pathway in PC-3 human prostatic adenocarcinoma cells (Rajah et al. 1997) as well as in other cell systems (Nickerson et al. 1997). We, therefore, hypothesized that IGFBP-3 may be a major downstream effector of growth inhibitory and apoptosis-inducing agents.

Indeed, $\mathrm{NaB}$ treatment significantly upregulated IGFBP-3 steady-state mRNA and protein levels in a timeand dose-dependent manner in Hs578T and MCF-7 human breast cancer cells, while levels of IGFBP-2 and -4 were unaffected. As summarized in Fig. 9, we observed that the mRNA induction had already started at $6 \mathrm{~h}$ after treatment and peaked by $24 \mathrm{~h}$ after treatment, while the presence of the protein in CM was barely detectable at the $24 \mathrm{~h}$ time point and gradually increased up to day 3 . Notably, both the mRNA and protein induction by $\mathrm{NaB}$ were detectable earlier than the reduction in cell number and apoptosis, consistent with a specific regulation of these IGFBP superfamily members by $\mathrm{NaB}$ rather than effects on these IGFBPs occurring secondary to cell death. In contrast to effects seen in these cancer cell lines, the $\mathrm{NaB}$ regulation of IGFBP-3 in normal human mammary epithelial cells was less marked. Additionally, treatment with TSA gave similar results, indicating that histone hyperacetylation may be involved. The differential regulation of IGFBP-3 by $\mathrm{NaB}$ in cancerous versus non-cancerous cells may point to an important mechanism for growth inhibition by IGFBP-3 in cancer.

It has been demonstrated that TGF- $\beta$, which is a potent growth suppressing factor in human breast cancer cells (Zugmaier et al. 1989, Oh et al. 1995), induces expression of IGFBP-rP2 mRNA and protein levels (Yang et al. 1998). In addition, recent studies have demonstrated that IGFBP-rP2 has a direct apoptotic effect in MCF-7 cells (Hishikawa et al. 1999). Our present data show that IGFBP-rP2 was significantly upregulated by $\mathrm{NaB}$ treatment in a time- and dose-dependent manner in both cancerous and non-cancerous human mammary epithelial cell lines, suggesting that IGFBP-rP2 may also play a role in the bioactivity of butyrate on cells. In Hs578T cells, the induction of IGFBP-rP2 mRNA was already marked at $0.5 \mathrm{mM}$, while the protein levels were significantly increased at $5 \mathrm{mM}$. One potential explanation for this dose discrepancy is that some post-transcriptional modification by $\mathrm{NaB}$ of IGFBP-rP2 may also be occurring.

On the basis of this work, it can be speculated that the IGFBP superfamily members, IGFBP-3 and IGFBP-rP2, participate in butyrate-induced sequential cell growth inhibition, particularly in the later event of apoptosis. Detailed studies involving regulation of IGFBP-3 and IGFBP-rP2 bioactivity following butyrate treatment in breast epithelial cells are now required to formally address this issue. It is hoped that exploration of butyrate-induced biological effects subsequent to the cell cycle arrest in this cell system and the investigation of the interaction between butyrate and the IGF axis will lead to a more complete understanding of the complex mechanisms of cell growth control, and to the development of better therapeutic reagents.

\section{Acknowledgements}

This research was supported by NIH grants R01 DK51513 (R G R) and CA58110 (R G R), and by US Army grants DAMD17-00-1-0042 (R G R), DAMD1796-1-6204 (Y O) and DAMD17-96-1-7204 (Y O).

\section{References}

Adamo ML, Shao ZM, Lanau F, Chen JC, Clemmons DR, Roberts CT Jr, LeRoith D \& Fontana JA 1992 Insulin-like growth factor-I (IGF-I) and retinoic acid modulation of IGF-binding proteins (IGFBPs): IGFBP-2, -3 , and -4 gene expression and protein secretion in a breast cancer cell line. Endocrinology 131 1858-1866.

Archer SY \& Hodin RA 1999 Histone acetylation and cancer. Current Opinion in Genetics and Development 9 171-174.

Archer SY, Meng S, Shei A \& Hodin RA 1998 p21 $1^{\mathrm{WAF} 1}$ is required for butyrate-mediated growth inhibition of human colon cancer cells. PNAS 95 6791-6796.

Baxter RC, Binoux MA, Clemmons DR, Conover CA, Drop SL, Holly JM, Mohan S, Oh Y \& Rosenfeld RG 1998

Recommendations for nomenclature of the insulin-like growth factor binding protein superfamily. Journal of Clinical Endocrinology and Metabolism 833213.

Buckbinder L, Talbott R, Velasco-Miguel S, Takenaka I, Faha B, Seizinger BR \& Kley N 1995 Induction of the growth inhibitor IGF-binding protein 3 by p53. Nature 377 646-649.

Burger AM, Zhang X, Li H, Ostrowski JL, Beatty B, Venanzoni M, Papas T \& Seth A 1998 Down-regulation of T1A12/mac25, a novel insulin-like growth factor binding protein related gene, is associated with disease progression in breast carcinomas. Oncogene 16 2459-2467.

Carducci MA, Nelson JB, Chan-Tack KM, Ayyagari SR, Sweatt WH, Campbell PA, Nelson WG \& Simons JW 1996

Phenylbutyrate induces apoptosis in human prostate cancer and is more potent than phenylacetate. Clinical Cancer Research 2 379-387.

Colston KW, Perks CM, Xie SP \& Holly JM 1998 Growth inhibition of both MCF-7 and Hs578T human breast cancer cell lines by vitamin $\mathrm{D}$ analogues is associated with increased expression of insulin-like growth factor binding protein-3. Journal of Molecular Endocrinology 20 157-162.

Coradini D, Biffi A, Costa A, Pellizzaro C, Pirronello E \& Di Fronzo G 1997 Effect of sodium butyrate on human breast cancer cell lines. Cell Proliferation 30 149-159.

Gleave ME, Sato N, Sadar M, Yago V, Bruchovsky N \& Sullivan L 1998 Butyrate analogue, isobutyramide, inhibits tumor growth and time to androgen-independent progression in the human prostate LNCaP tumor model. Journal of Cellular Biochemistry 69 271-281.

Gucev ZS, Oh Y, Kelley KM \& Rosenfeld RG 1996 Insulin-like growth factor binding protein 3 mediates retinoic acid- and transforming growth factor $\beta 2$-induced growth inhibition in human breast cancer cells. Cancer Research 56 1545-1550.

de Haan JB, Gevers W \& Parker MI 1986 Effects of sodium butyrate on the synthesis and methylation of DNA in normal cells and their transformed counterparts. Cancer Research 46 713-716. 
Hague A, Manning AM, Hanlon KA, Huschtscha LI, Hart D \& Paraskeva C 1993 Sodium butyrate induces apoptosis in human colonic tumour cell lines in a p53-independent pathway: implications for the possible role of dietary fibre in the prevention of large-bowel cancer. International Journal of Cancer 55 498-505.

Hague A, Díaz GD, Hicks DJ, Krajewski S, Reed JC \& Paraskeva C 1997 bcl-2 and bak may play a pivotal role in sodium butyrateinduced apoptosis in colonic epithelial cells; however overexpression of bcl-2 does not protect against bak-mediated apoptosis. International Journal of Cancer 72 898-905.

Hassig CA, Tong JK \& Schreiber SL 1997 Fiber-derived butyrate and the prevention of colon cancer. Chemistry and Biology 4 783-789.

Hishikawa K, Oemar BS, Tanner FC, Nakaki T, Lüscher TF \& Fujii T 1999 Connective tissue growth factor induces apoptosis in human breast cancer cell line MCF-7. Journal of Biological Chemistry 274 37461-37466.

Huang H, Reed CP, Zhang JS, Shridhar V, Wang L \& Smith DI 1999 Carboxypeptidase A3 (CPA3): a novel gene highly induced by histone deacetylase inhibitors during differentiation of prostate epithelial cancer cells. Cancer Research 59 2981-2988.

Hunter T \& Pines J 1994 Cyclins and cancer. II: cyclin D and CDK inhibitors come of age. Cell 79 573-582.

Huynh H, Yang X \& Pollak M 1996 Estradiol and antiestrogens regulate a growth inhibitory insulin-like growth factor binding protein 3 autocrine loop in human breast cancer cells. Journal of Biological Chemistry 271 1016-1021.

Hwa V, Oh Y \& Rosenfeld RG 1999 Insulin-like growth factor binding proteins: a proposed superfamily. Acta Paediatrica. Supplement 428 37-45.

Kaufmann SH, Desnoyers S, Ottaviano Y, Davidson NE \& Poirier GG 1993 Specific proteolytic cleavage of poly (ADP-ribose) polymerase: an early marker of chemotherapy-induced apoptosis. Cancer Research 53 3976-3985.

Kelley KM, Oh Y, Gargosky SE, Gucev Z, Matsumoto T, Hwa V, Ng L, Simpson DM \& Rosenfeld RG 1996 Insulin-like growth factor-binding proteins and their regulatory dynamics. International Journal of Biochemistry and Cell Biology 28 619-637.

Knabbe C, Lippman ME, Wakefield LM, Flanders KC, Kasid A, Derynck R \& Dickson RB 1987 Evidence that transforming growth factor- $\beta$ is a hormonally regulated negative growth factor in human breast cancer cells. Cell 48 417-428.

Lallemand F, Courilleau D, Sabbah M, Redeuilh G \& Mester J 1996 Direct inhibition of the expression of cyclin D1 gene by sodium butyrate. Biochemical and Biophysical Research Communications 229 163-169.

Lallemand F, Courilleau D, Buquet-Fagot C, Atfi A, Montagne MN \& Mester J 1999 Sodium butyrate induces G2 arrest in the human breast cancer cells MDA-MB-231 and renders them competent for DNA rereplication. Experimental Cell Research 247 432-440.

Lazebnik YA, Kaufmann SH, Desnoyers S, Poirier GG \& Earnshaw WC 1994 Cleavage of poly (ADP-ribose) polymerase by a proteinase with properties like ICE. Nature 371 346-347.

Litvak DA, Evers M, Hwang KO, Hellmich MR, Ko TC \& Townsend CM Jr 1998 Butyrate-induced differentiation of Caco-2 cells is associated with apoptosis and early induction of $\mathrm{p} 21^{\text {Waf1/Cip } 1}$ and $\mathrm{p} 27^{\mathrm{Kip} 1}$. Surgery 124 161-170.

Macaulay VM 1992 Insulin-like growth factors and cancer. British Journal of Cancer 65 311-320.

Mandal M \& Kumar R 1996 Bcl-2 expression regulates sodium butyrate-induced apoptosis in human MCF-7 breast cancer cells. Cell Growth and Differentiation 7 311-318.

Nakano K, Mizuno T, Sowa Y, Orita T, Yoshino T, Okuyama Y, Fujita T, Ohtani-Fujita N, Matsukawa Y, Tokino T, Yamagishi H, Oka T, Nomura H \& Sakai T 1997 Butyrate activates the WAF1/Cip1 gene promoter through $\mathrm{Sp} 1$ sites in a p53-negative human colon cancer cell line. Journal of Biological Chemistry 272 22199-22206.
Nickerson T, Huynh H \& Pollak M 1997 Insulin-like growth factor binding protein-3 induces apoptosis in MCF7 breast cancer cells. Biochemical and Biophysical Research Communications 237 690-693.

Nishimura A, Fujimoto M, Oguchi S, Fusunyan RD, MacDermott RP \& Sanderson IR 1998 Short-chain fatty acids regulate IGF-binding protein secretion by intestinal epithelial cells. American Journal of Physiology 275 E55-E63.

Ogryzko VV, Wong P \& Howard BH 1997 WAF1 retards S-phase progression primarily by inhibition of cyclin-dependent kinases. Molecular and Cellular Biology 17 4877-4882.

Oh Y 1998 IGF-independent regulation of breast cancer growth by IGF binding proteins. Breast Cancer Research and Treatment 47 283-293.

Oh Y, Müller HL, Lamson G \& Rosenfeld RG 1993 Insulin-like growth factor (IGF)- independent action of IGF-binding protein-3 in Hs578T human breast cancer cells. Cell surface binding and growth inhibition. Journal of Biological Chemistry 268 14964-14971.

Oh Y, Müller HL, Ng L \& Rosenfeld RG 1995 Transforming growth factor- $\beta$-induced cell growth inhibition in human breast cancer cells is mediated through insulin-like growth factor-binding protein-3 action. Journal of Biological Chemistry 270 13589-13592.

Pouillart PR 1998 Role of butyric acid and its derivatives in the treatment of colorectal cancer and hemoglobinopathies. Life Sciences 63 1739-1760.

Rajah R, Valentinis B \& Cohen P 1997 Insulin-like growth factor (IGF)-binding protein-3 induces apoptosis and mediates the effects of transforming growth factor- $\beta 1$ on programmed cell death through a p53- and IGF-independent mechanism. Journal of Biological Chemistry 272 12181-12188.

Rajaram S, Baylink DJ \& Mohan S 1997 Insulin-like growth factorbinding proteins in serum and other biological fluids: regulation and functions. Endocrine Reviews 18 801-831.

Resnicoff M, Abraham D, Yutanawiboonchai W, Rotman HL, Kajstura J, Rubin R, Zoltick P \& Baserga R 1995 The insulin-like growth factor I receptor protects tumor cells from apoptosis in vivo. Cancer Research 55 2463-2469.

Rosenfeld RG, Lamson G, Pham H, Oh Y, Conover C, De Leon DD, Donovan SM, Ocrant I \& Giudice L 1990 Insulin-like growth factor binding proteins. Recent Progress in Hormone Research 46 99-159.

Rozen F, Zhang J \& Pollak M 1998 Antiproliferative action of tumor necrosis factor-alpha on MCF-7 breast cancer cells is associated with increased insulin-like growth factor binding protein-3 accumulation. International Journal of Oncology 13 865-869.

Schwartz B, Avivi-Green C \& Polak-Charcon S 1998 Sodium butyrate induces retinoblastoma protein dephosphorylation, p16 expression and growth arrest of colon cancer cells. Molecular and Cellular Biochemistry 188 21-30.

Sheikh MS, Shao ZM, Clemmons DR, LeRoith D, Roberts CT Jr \& Fontana JA 1992 Identification of the insulin-like growth factor binding proteins 5 and 6 (IGFBP-5 and 6) in human breast cancer cells. Biochemical and Biophysical Research Communications $\mathbf{1 8 3}$ 1003-1010.

Siavoshian S, Blottiere HM, Cherbut C \& Galmiche JP 1997 Butyrate stimulates cyclin D and p21 and inhibits cyclin-dependent kinase 2 expression in HT-29 colonic epithelial cells. Biochemical and Biophysical Research Communications 232 169-172.

Staiano-Coico L, Khandke L, Krane JF, Sharif S, Gottlieb AB, Krueger JG, Heim L, Rigas B \& Higgins PJ 1990 TGF- $\alpha$ and TGF- $\beta$ expression during sodium-n-butyrate-induced differentiation of human keratinocytes: evidence for subpopulation-specific up-regulation of TGF- $\beta$ mRNA in suprabasal cells. Experimental Cell Research 191 286-291.

Valentinis B, Bhala A, DeAngelis T, Baserga R \& Cohen P 1995 The human insulin-like growth factor (IGF) binding protein-3 inhibits the growth of fibroblasts with a targeted disruption of the IGF-I receptor gene. Molecular Endocrinology 9 361-367. 
Vaziri C, Stice L \& Faller DV 1998 Butyrate-induced G1 arrest results from $\mathrm{p} 21$-independent disruption of retinoblastoma proteinmediated signals. Cell Growth and Differentiation 9 465-474.

Velázquez OC, Lederer HM \& Rombeau JL 1997 Butyrate and the colonocyte. Production, absorption, metabolism, and therapeutic implication. Advances in Experimental Medicine and Biology 427 123-134.

Wilson EM, Oh Y \& Rosenfeld RG 1997 Generation and characterization of IGFBP-7 antibody: identification of $31 \mathrm{kD}$ IGFBP-7 in human biological fluids and Hs578T human breast cancer conditioned media. Journal of Clinical Endocrinology and Metabolism 82 1301-1303.

Yamamoto H, Fujimoto J, Okamoto E, Furuyama J, Tamaoki T \& Hashimoto-Tamaoki T 1998 Suppression of growth of hepatocellular carcinoma by sodium butyrate in vitro and in vivo. International Journal of Cancer 76 897-902.

Yang DH, Kim HS, Wilson EM, Rosenfeld RG \& Oh Y 1998 Identification of glycosylated $38-\mathrm{kD}$ a connective tissue growth factor (IGFBP-related protein 2) and proteolytic fragments in human biological fluids, and up-regulation of IGFBP-rP2 expression by TGF- $\beta$ in Hs578T human breast cancer cells. Journal of Clinical Endocrinology and Metabolism 83 2593-2596.

Yoshida M, Kijima M, Akita M \& Beppu T 1990 Potent and specific inhibition of mammalian histone deacetylase both in vivo and in vitro by trichostatin A. Journal of Biological Chemistry 265 17174-17179.

Zugmaier G, Ennis BW, Deschauer B, Katz D, Knabbe C, Wilding G, Daly P, Lippman ME \& Dickson RB 1989 Transforming growth factors type $\beta 1$ and $\beta 2$ are equipotent growth inhibitors of human breast cancer cell lines. Journal of Cellular Physiology 141 353-361.

Received 21 November 2000

Accepted 8 December 2000 